once again to check the same place and was surprised to find a healthy looking specimen with a flowering stem developing. Apparently I must have missed the first year rosette in 1963. This specimen during the season grew to a height of about four feet.

Common Mullein, according to the reference books at the local library, has a number of other common names which include: Velvet Dock, Aaron's Rod, Adam's Flannel, Flannel Leaf, Blanket Leaf, Candle Leaf, Velvet Plant, Feltwort, Wild Tobacco, and Devil's Tobacco. In the book "Stalking the Wild Asparagus" (Gibbons, 1962), under a chapter dealing with folk medicine, it is mentioned as an ingredient of a cough syrup. Along with mullein, the concoction included white spruce, wild cherry and red clover. In Europe during the Middle Ages part of this plant was used in the making of candlewicks which probably accounts for one of its common names, Candle Leaf.

This location in the C.N.R. yards at Saskatoon is to be redeveloped into an industrial park and it is quite likely that bulldozers and other earthmoving machinery will be working in this area in the near future. I consider it unlikely that this plant will survive here. With this in mind I collected the specimen and delivered it to Dr. George W. Argus, W. P. Fraser Herbarium, University of Saskatchewan at Saskatoon.

\title{
Bluebur - A Weedy Pest
}

by Keith F. Best, Swift Current

Bluebur (Lappula enchinata) (Gilib.), also called stickseed, burseed and sticktight, is so named because of the burlike nutlets which cling to clothing and to the fur of animals. This plant is a member of the borage family (Boraginaceae) and derives its name Lappula, meaning little bur, from the Latin lappa, a bur. Introduced from Europe, Bluebur is now widely distributed in the West, but is usually only abundant in waste places such as roadsides and fencelines. Bluebur is frequently a pest in fields and pastures, often increasing on overgrazed range. The seeds which cling tightly to clothing and become entangled in the manes and tails of cattle and horses, as well as in the wool of sheep, are annoying to both man and beast.

A much-branched hairy annual or winter annual, bluebur grows from six inches to two feet in height. The alternate, narrow leaves are one to three inches long, the upper ones being stalkless, the lower ones generally stalked. The pale blue flowers are about $1 / 8$ inch across and are found in erect racemes at the ends of the branches. The fruit consists of four nutlets with two rows of hooked prickles around the margins. The whole plant has a rather unpleasant smell like that of a mouse-infested building.

Bluebur is practically worthless as forage for cattle and horses and rates only as poor to fair for sheep.

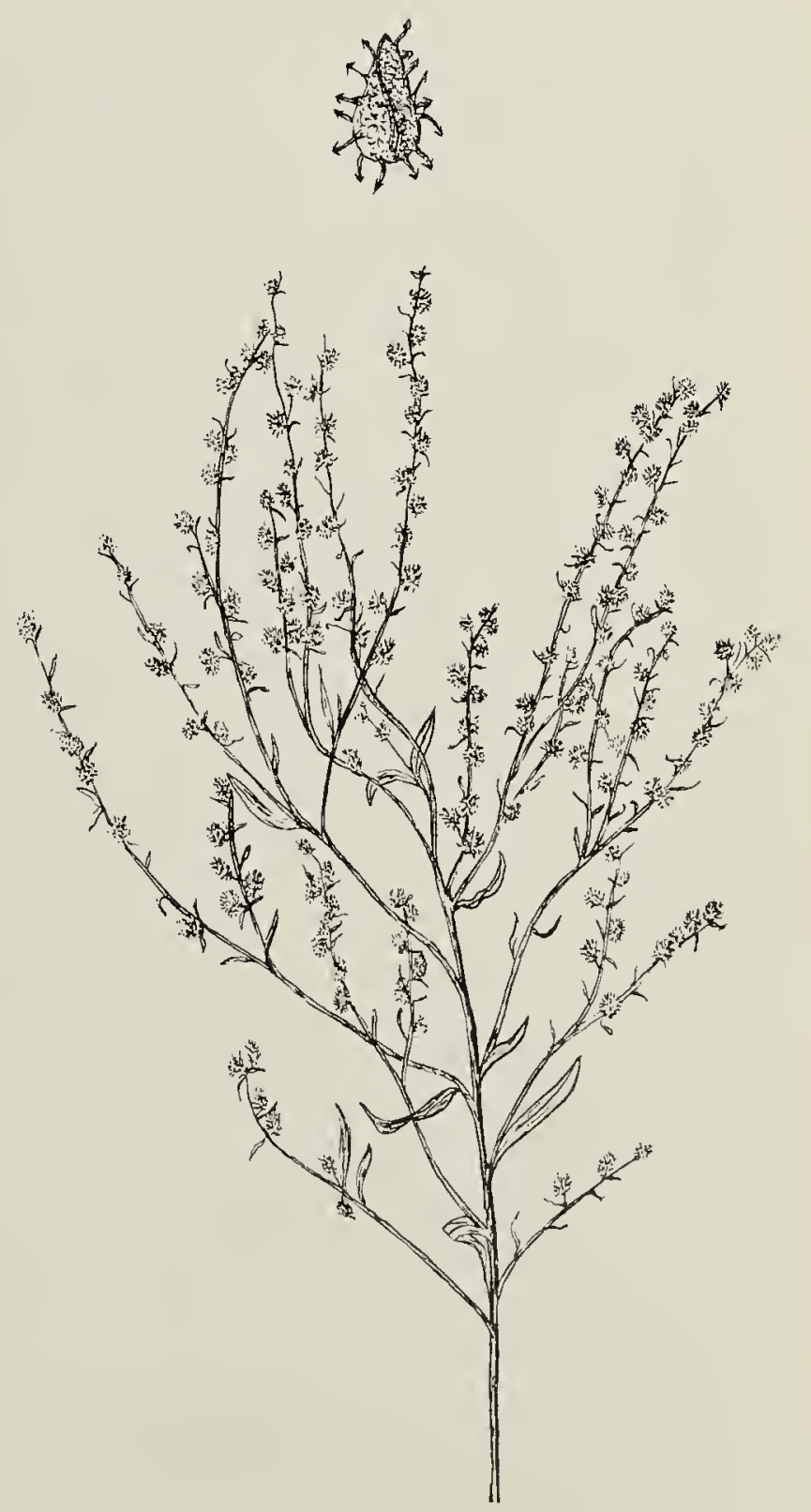

Drawing by K. F. Best

Bluebur-Lappula echinata 